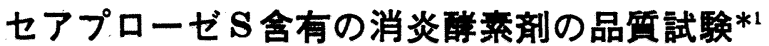

\author{
田部和久 ${ }^{* 2}$, 益池 豊, 大西 昇, 平岡栄一*3 \\ 大阪大学微生物病研究所付属病院薬㓮部*2 \\ 大阪大学医学部付属病院薬剤部*3
}

\section{Quality Test of Anti-inflammatory Enzyme Preparations Containing Seaprose $\mathbf{S}^{* 1}$}

\author{
KAZUHISA TANABE*2, YUTAKa MASUIKe, NoBorU OHNISHI, \\ and EIICHI HIRAOKA*3 \\ Department of Pharmacy, Hospital Attached to the Research Institute for Microbial \\ Diseases, Osaka University*2, Department of Pharmacy, Osaka University Hospital*3
}

(Received September 3, 1979)

\begin{abstract}
To evaluate quality of 3 brands of capsules (A, B and C) and 2 brands of tablets (D and E) of seaprose $\mathrm{S}$, weight variation test, content test and dissolution test were made. All products met weight variation test of capsule or tablet (J. P. IX). In the content test, mean content percentage of products $\mathrm{B}$ and $\mathrm{C}$ were about $82 \%$ of each labeled amount and those of the remaining 3 products were not less than $90 \%$. To test acid resistance of the enteric-coated films of each product, activity of seaprose $S$ dissolved in the 1st fluid and the 2nd fluid of disintegration test (J. P. IX) were determined. It was found that the acid resistance of the enteric-coated granules of products A and B was insufficient ; especially, the activity of product $A$ dissolved in the 2nd fluid decreased to a half of the activity recorded in the content test. Then, to find the cause of the decrease in activity, protein content and activity of seaprose $\mathrm{S}$ dissolved in both fluids were measured simultaneously. It is suggested that seaprose $S$ in granules was partially deactivated by permeation of the 1st fluid through the enteric-coated films and, after that, seaprose $\mathrm{S}$ was slowly dissolved in the test fluids. Maximum activities of products $\mathrm{A}$ and $\mathrm{B}$ in $\mathrm{pH}$ shift test solution were 20 and $30 \%$, respectively, of those recorded in the content test. It is, as a result, considered that products $\mathrm{D}$ and $\mathrm{E}$ are satisfactory enteric-coated preparations.
\end{abstract}

\section{はじめに}

前報1) では 5 種類の市販消炎酵素剤の品質を評価する 目的から, 各種試験液を用いて溶出する酵素の力価を测 定し, 特に腸溶性製剤では，その皮膜の耐酸性が酵素の 失活を防止するらえで非常に重要であることを述べた。 また腸溶性皮膜の品質を試験する場合, 経時的 $\mathrm{pH}$ 変化

*1 日本薬学会第98年会（岡山，1978）で発表.

*2 吹田市大字山田上; Yamadakami, Suita-shi, 565 Japan

*3 大阪市福島区福島 1 丁目 1-50；1-50，Fukushima 1-chome, Fukushima-ku, Osaka, 553 Japan
試験液を用いるのが有効であることを認めた：さらに， 総合消化酵素剤の腸溶性皮膜の 品質を 評価する場合に も, この試験方法が有効であることを確認した22.

前報での消炎酵素剂のうち一部の腸溶性製剂は, 経時 的 $\mathrm{pH}$ 変化試験での酵素力価が至適 $\mathrm{pH}$ での力価の $50 \%$ 以下に低下した. 腸溶性酵素製剂の力価が低下する過程 については報告されていないので, 今回は消炎作用を有 するセフプローゼSのみを含有する 5 種類の製剂を用 い, 試験液に溶出する酵素力価および酵素たん白量を同 時に湘定し，力価低下の原因について検討したまた， 品質を総合的に評価するために, 重量偏差試験, 含量試 験をす併せて行ったので報告する. 


\section{実 騋 方 法}

\section{1. 試 料}

実験に使用したセアプローゼ $\mathrm{S}$ 含有の消炎酵素剂 5 種
類を Table 1 に示す. 試料A，B および C は腸溶性顆 粒を内容物としたカプセル阂で，試料DおよびEは腸容 性錠剤である、なお，実験にはすべて同一ロット番号の 製剤を使用した。

Table 1. Seaprose S Preparations Used in Experiment

\begin{tabular}{c|l|l|c}
\hline \hline Product & Formulation & Lot No. & $\begin{array}{c}\text { Labeled Amount } \\
\text { (mg) }\end{array}$ \\
\hline A & capsule & WG290570 & 10 \\
B & capsule & J2025AT24EW & 10 \\
C & capsule & E30WF & 10 \\
D & tablet & N6277170 & 5 \\
E & tablet & B31WE & 5 \\
\hline
\end{tabular}

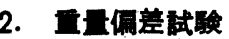

「日局 $9 」$ の鐎剤およびカプセル剂の重量偏差試験法 に従った。

\section{3. セアプローゼS カ価の測定法}

力価の測定は, Casein-Folin・B法3)により行った. 検量線はチロジンを用いて作製し，酵素力価の表示は生 成チロジン量 $(\mathrm{mg} / \mathrm{min} / \mathrm{capsule}$ or tablet) で示した. また，セアプローゼ $\mathrm{S}$ 原末を用いて上記の方法で力価を 求めて検量線を作製し，酵素力価より活性酵素量（活性 たん白量)を求めた。

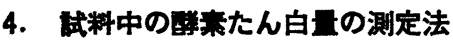

試料から試験液に溶出した酵素量を測定する場合，た ん白量として求める方法がある. 既知量の活性セアプロ 一ゼ S および失活セアプローゼ S について銅-Folin法4) を改变した方法で酵素量を測定した結果，同一吸光度と なったので，試験液中に活性および失活したセアプロー せ S が共存し，その比率が異なっても測定による酵素量 は同一となる．今回はこの 銅-Folin 法を用いて，各製 版から試験液中に溶出する酵素たん白量を求めた。

すなわち，予めアルカリ性銅試薬として，試薬 $\mathrm{A}$ 液 (炭酸ナトリウム $2 \mathrm{~g}$ を $0.1 \mathrm{~N} \mathrm{NaOH} て ゙$ 溶解して 100 $\mathrm{m} \ell$ とした $50 \mathrm{ml}$ ， と，試薬 B液 (硫酸銅 ( 5 水和物) 0.5 $\mathrm{g}$ と酒石酸ナトリウム $0.1 \mathrm{~g}$ を精製水で溶解して $100 \mathrm{~m} \ell$ とした） $1 \mathrm{~m} \ell$ とを用時調製して混和した．溶出した酵素

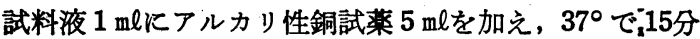
間加温し，次に 2 倍希釈フォリン試薬 $0.5 \mathrm{~m} \ell$ を加えて発
色させ， $37^{\circ}$ で20分間加温後ろ過し，波長 $750 \mathrm{~nm}$ の吸 光度 $\left(\mathrm{B}_{1}\right)$ を測定した. 対照として, 酵素試料液の代わ りに $\mathrm{pH} 8.0$ の緩衝液を用い，同様の操作で発色させて 吸光度 $\left(\mathrm{B}_{2}\right)$ を測定した.なお，セアプローゼ $\mathrm{S}$ 原末を 用いて検量線を作製し，吸光度差 $\left(\mathrm{B}_{1}-\mathrm{B}_{2}\right)$ よりセてブ ローゼSとしての酵素たん白量を算出した。

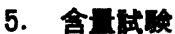

$50 \mathrm{ml}$ のメスフラスコに試料 1 個 および $\mathrm{pH} 8.0$ 緩衝液 $25 \mathrm{ml}$ をれ， $25^{\circ} て ゙ 20$ 分間振とらして溶解後，同じ緩 衝液で全量 $50 \mathrm{ml}$ とし, さらに緩衝液で希釈して前述の 酵素力価の測定法に従って力価を求めた. 別に, 表示量 のセアプローゼ $\mathrm{S}$ 原末を用いて力価を求め, その值を含 量 $100 \%$ とし，上記力価より含量\%を算出した。

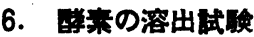

酵素の溶出試験は，「日局 $9 」$ 崩壊試験装置を用い， 試験器の補助筒内に錠剤またはカプセル内容物の顆粒を 入れ, $37 \pm 2^{\circ}$ 飞保った試験液 $1000 \mathrm{ml}$ 中で上下運動を行 い,一定時間毎に採取した。

6-1. 一定 $\mathrm{pH}$ 試験液による測定

$\mathrm{pH} 6.2,7.2$ および 8.0 の試験液を 用い，溶出する酵 素の力価を 120 分まで測定した.

6-2.「日局 9 」崩壊試験法の第 1 液, 第 2 液に上る測 定

錠風は第 1 液で 120 分, カプセル内容物の顆粒は 60 分 上下運動し，速やかに第 2 液に移して60分まで採取し， 酵素力価および酵素たん白量を測定した。 
6-3. 経時的 $\mathrm{pH}$ 変化試験液1)による測定

薬物の消化管内移行に伴う $\mathrm{pH}$ 变化を゙考慮して調製し た試験液で，初期試験液の $\mathrm{pH}$ を 2.6 とし，pH を徐々に 変化させて 5 時間後の $\mathrm{pH}$ が 7 付近となるように調整し， 溶出する酵素力価および酵素たん白量を測定した。

\section{実䲗結果および宩寮}

\section{1. 工具漏差試駧}

「日局 $9 」$ の錠剂およびカプセル剂の重量偏差試験法
に従い測定した結果を Table 2 に示した。全試料とも 変動係数は $1.0 〜 2.5 \%$ と非常に小さかった.

\section{2. 含豆試験}

各試料 10 個について含量試験を行った結果を Table 3 に示した. 試料 $\mathrm{A}, \mathrm{D}$ および $\mathrm{E}$ は平均含量が $90 \%$ 以上 であったが，試料 $\mathrm{B} ， \mathrm{C}$ は約 $82 \%$ と低い值となった。 カ プセル内の顆粒 $\mathrm{A}, \mathrm{B}$ およ゙ Cは, 錠剤 D, Eに比して 平均含量\%は低い值となった。試料 $\mathrm{B}, \mathrm{C}, \mathrm{D}$ おび $\mathrm{E}$ は，含量\%の変動係数が $3 \%$ 以下であった．著者らら は

Table 2. Results of Weight Variation Test for Seaprose S Preparations

\begin{tabular}{l|c|c|c|c}
\hline \hline Product & $\begin{array}{r}\text { Mean } \pm \text { S.D. } \\
(\mathrm{mg})\end{array}$ & $\begin{array}{r}\text { Max. } \\
(\mathrm{mg})\end{array}$ & $\begin{array}{r}\text { Min. } \\
(\mathrm{mg})\end{array}$ & $\begin{array}{r}\mathrm{C} . \mathrm{V} . \\
(8)\end{array}$ \\
\hline A & $221.2 \pm 5.6$ & 232.3 & 213.1 & 2.5 \\
B & $336.2 \pm 5.4$ & 349.3 & 325.6 & 1.6 \\
C & $260.6 \pm 5.7$ & 268.3 & 251.3 & 2.2 \\
D & $206.9 \pm 2.0$ & 210.3 & 202.1 & 1.0 \\
E & $159.6 \pm 4.0$ & 167.3 & 149.4 & 2.5 \\
\hline
\end{tabular}

消化酵素カプセル剂の晹溶性部分の重量とアルカリ性プ ロテアーゼ活性との間に良好な相関性を認めた。そこで 今回の試料についても同様の検討を試みた結果, カプセ ル剂， $\mathrm{A}, \mathrm{B}$ およびCの顆粒部分では相関係数 0.8 以上
であり相関性が認められた。

3. 一定 pH 試䮦液に溶出するセアプローゼ Sのカ俩

各試料と夕腸溶性製剤であるので, 皮膜の溶解し始め る $\mathrm{pH}$ 扎よびセアプローゼ Sの至適 $\mathrm{pH}$ 領域での酵素の溶

Table 3. Results of Content Test for Seaprose S Preparations

\begin{tabular}{l|c|c|c|c}
\hline \hline & \multicolumn{3}{c}{$\mathrm{n}=10$} \\
\hline Product & Mean $\pm \begin{array}{c}\text { S.D. } \\
(\%)\end{array}$ & $\begin{array}{c}\text { Max. } \\
(8)\end{array}$ & $\begin{array}{c}\text { Min. } \\
(\%)\end{array}$ & $\begin{array}{r}\text { C.V. } \\
(\%)\end{array}$ \\
\hline A & $90.7 \pm 3.7$ & 96.0 & 83.0 & 3.8 \\
B & $81.6 \pm .2 .1$ & 85.4 & 77.8 & 2.6 \\
C & $81.9 \pm 1.7$ & 84.4 & 79.5 & 2.1 \\
D & $94.2 \pm 2.6$ & 98.5 & 90.3 & 2.8 \\
E & $94.0 \pm 2.0$ & 100.6 & 91.7 & 2.7 \\
\hline
\end{tabular}

出性と溶出後の安定性について検討した.

$\mathrm{pH} 6.2$ の試験液に溶出したセアプローゼ S の力価曲線
をFig. 1 に示した. 試料A，BおよびDは 20 分後には 最高力価を示し, 120 分後も力価低下はほとんど認めら 


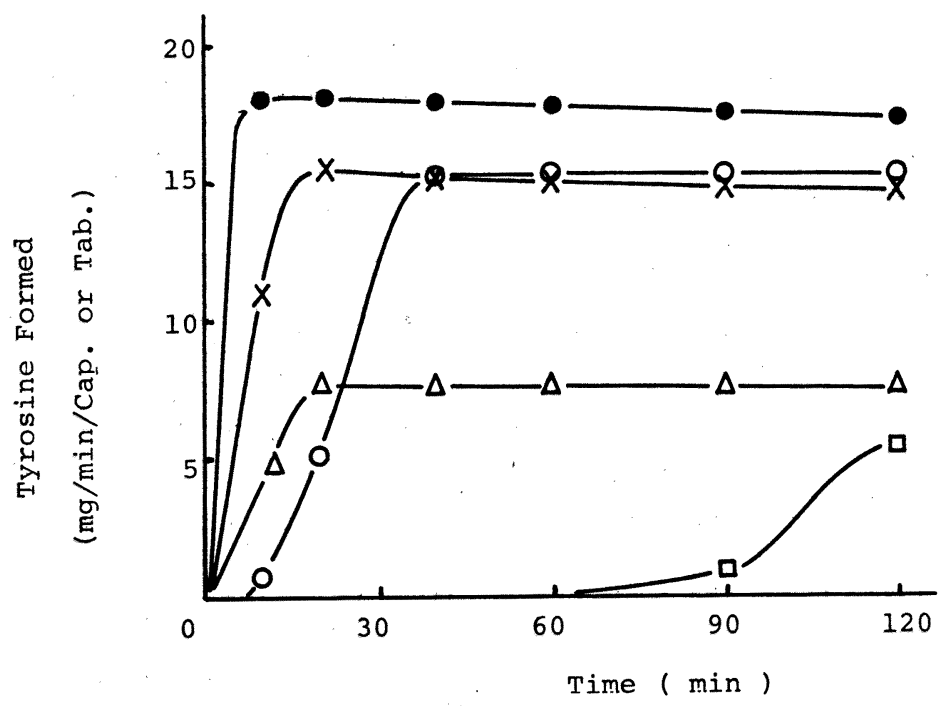

Fig. 1. Activities of Seaprose S Dissolved from Preparations in $\mathrm{pH} 6.2$ Test Solution

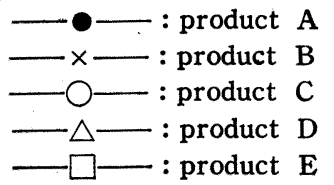

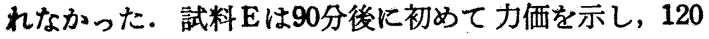
分後でも完全に崩壊していない製剤が観察された。

$\mathrm{pH} 7.2$ の試験液に溶出したセアプローゼ S の力価曲線 を Fig. 2 と示した. $\mathrm{pH} 6.2$ と同様, 試料 $\mathrm{E}$ のみが最高 力価を示すまでの時間は遅かったが，各試料とも 120 分 後の力価は最高力価にほぼ等しかった.

$\mathrm{pH} 8.0$ の試験液に溶出したセアプローゼ S の力価曲線 を Fig. 3 に示した. 各試料は最高力価を示した後は力 価が徐々に低下し，120 分後試料 $\mathrm{A}, \mathrm{E}$ は約 $10 \%$, 試料 B，CおよびDは約20\%減少した。これはセアプローゼ $\mathrm{S}$ の自己消化による活性低下であううと推察している.

3 種類の試験液の力価曲線から, 各試料とも製剤の崩 壊に伴い力価は上昇し, 最高力価は 3 種の試験液ともほ ぼ同じ值となった。

\section{4.「日局 $9 」$ 崩丧試験法の第 1 液・第 2 液に溶出す} るセアプローゼSのカ価とたん白量

セアプローゼ S は胃液のような強酸性の条件では速や かに失活するので, 腸溶性皮膜を施した製剤になってい ๖.この皮膜の耐酸性を検討する目的から，「日局 9 」崩 擤試験法の腸溶性の製剤の項に従い, 第 1 液および第 2
液に溶出するセアプローゼSの力価を測定した（Fig. 4). 第 1 液では各試料とも力価は認められなかった．第 2 液では試料 $\mathrm{E}$ 除く 4 試料は10分後に最高力価を示し た. また，各試料の60分後の力洒は最高力価等しかっ た.これらの力価曲線を $\mathrm{pH} 7.2$ の力価曲線 (Fig. 2) と 比較すると，鏔剤Dおよび $\mathrm{E}$ の最高力価は同一であった が，カプセル剤内容物の顆粒では最高力価の低下が認め られ，試料 A $50 \%$ ，試料Bは $20 \%$ 低下した。

そこで，力価が低下する原因を明確にするために，第 1 液および第 2 液に溶出するセアプローゼ $\mathrm{S}$ の力価と たん白量とを同時に測定し，その結果をカプセル剤は Fig. 5 K，錠剤は Fig. 6 に示した. カプセル内容物 の顆粒の試料BおよびCは第 1 液に溶出するたん白は認 められなかったが, 第 2 液での酵素力価から算出した活 性たん白量 (活性酵素量) は試料 Bが $6.7 \mathrm{mg}$, 試料 C

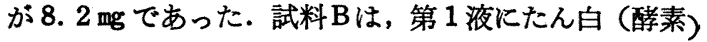
が溶出せず, 含量試験での平均活性たん白量は $8.2 \mathrm{mg}$ あったことから，第 2 液で活性たん白量が $1.5 \mathrm{mg}$ ほど低 下したのは, 第 1 液が皮膜内へ浸透したことによる失活 が主たる原因であると考えられる.一方, 試料Aは，第 


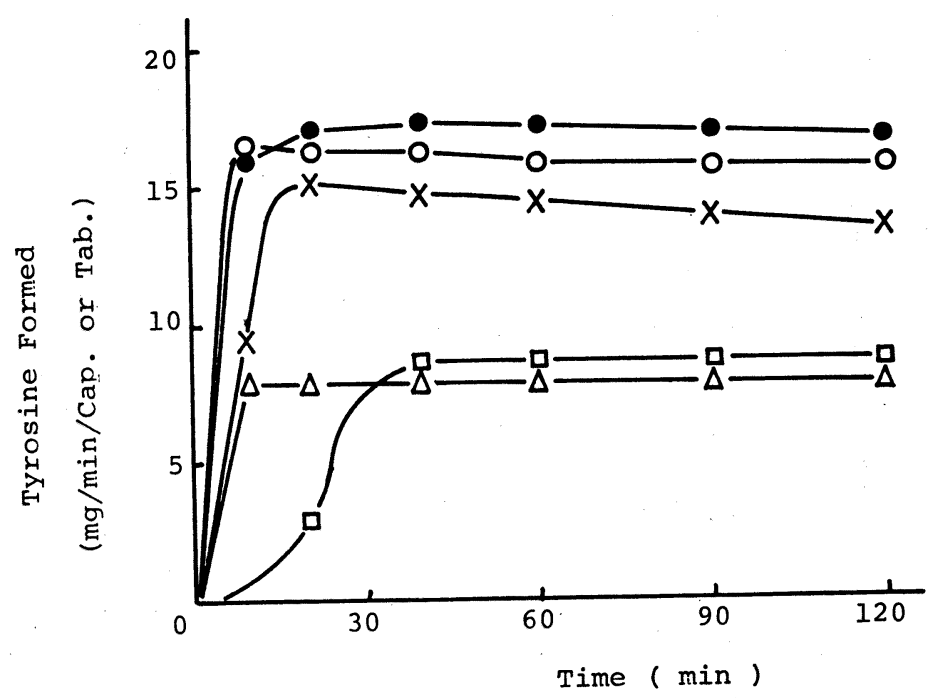

Fig. 2. Activities of Seaprose S Dissolved from Preparations in $\mathrm{pH} 7.2$ Test Solution

-

$-\times-$ : product $B$

$-\mathrm{O}-$ : product $\mathrm{C}$

$-\triangle \longrightarrow$ : product $\mathrm{D}$

$\longrightarrow \square-$ product $\mathrm{E}$

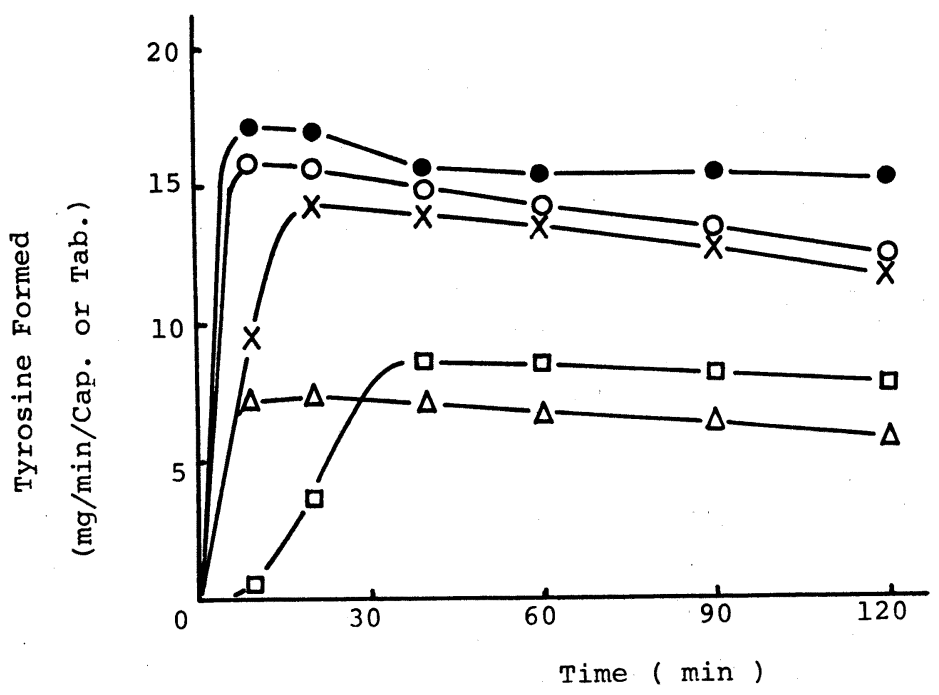

Fig. 3. Activities of Seaprose S Dissolved from Preparations in $\mathrm{pH} \mathrm{8.0} \mathrm{Test} \mathrm{Solution}$

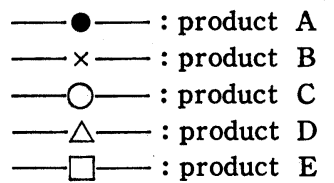




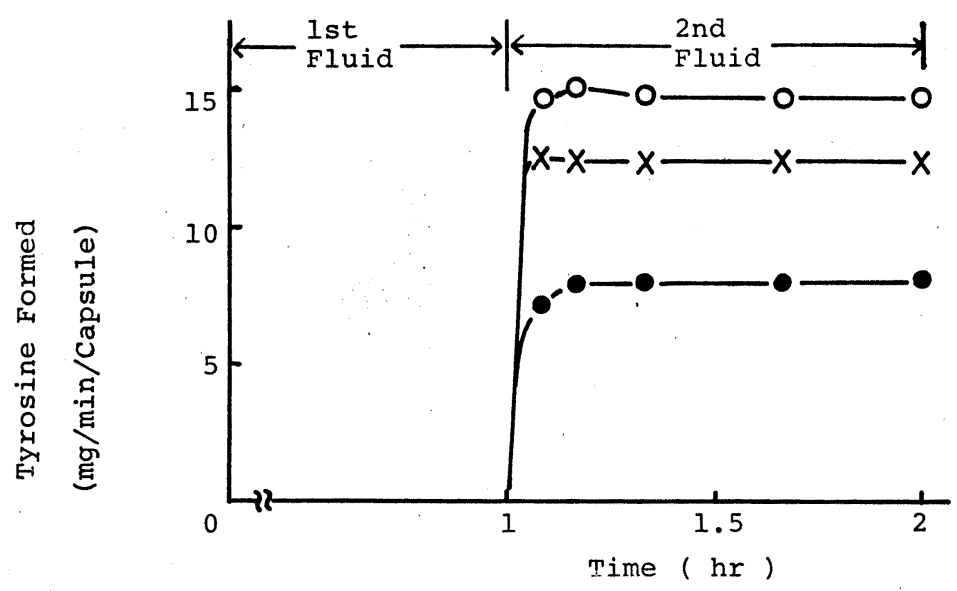

( a ) Capsule

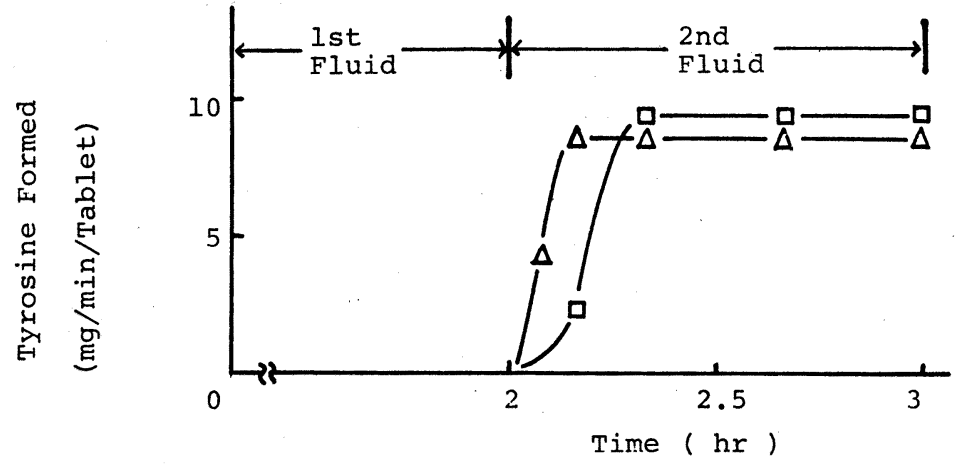

( b ) Tablet

Fig. 4. Activities of Seaprose S Dissolved from Preparations in Disintegration Test Fluids (J.P.IX)

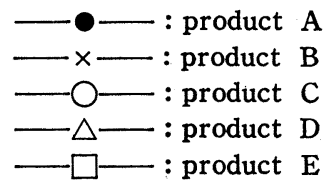

1 液の15分後には溶出するたん白（酵素）を認め, 60分 後のたん白量は $2 \mathrm{mg}$ あ゙あったが, 力価は認められなかっ た.この製剤 1 個の平均活性たん白量は, 含量試験より $9.1 \mathrm{mg}$ なので第 2 液には活性なたん白が約 $7 \mathrm{mg}$ 溶出す ると予測されたが, 実際には $4 \mathrm{mg}$ と低い值となったの で, 第 1 液の60分後には顆粒内の酵素も一部失活してい たことになる.したがって，第 1 液の60分後には, 試料 $\mathrm{A}$ の失活したセフプローゼ S は顆粒内と試験液中とに共 存していたと考えられる.

つぎに錠凨の試料 D および $\mathrm{E}$ 第 1 液へのたん白 （酵素）の溶出は認められず，第 2 液での活性たん白量
は含量試験から算出した平均活性たん白量と同一值であ ったので，腸溶性皮膜は十分な耐酸性を有しているとい える.

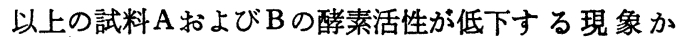
ら，まず第 1 液が皮膜内に浸透してセアプローゼ S が一 部失活し, その後徐々に溶出してくると推察される.た だ試料 $\mathrm{A}$ の場合，活性なセアプローゼ $\mathrm{S} か ゙$ 第 1 液に溶出 するか否かは明らかでない。

5. 耘時的 $\mathrm{pH}$ 変化侙験液に溶出するセアプローセ $\mathrm{S}$ のカ価とたん白至

前報の経時的 $\mathrm{pH}$ 変化試 験液を用い, カプセル中に顆 


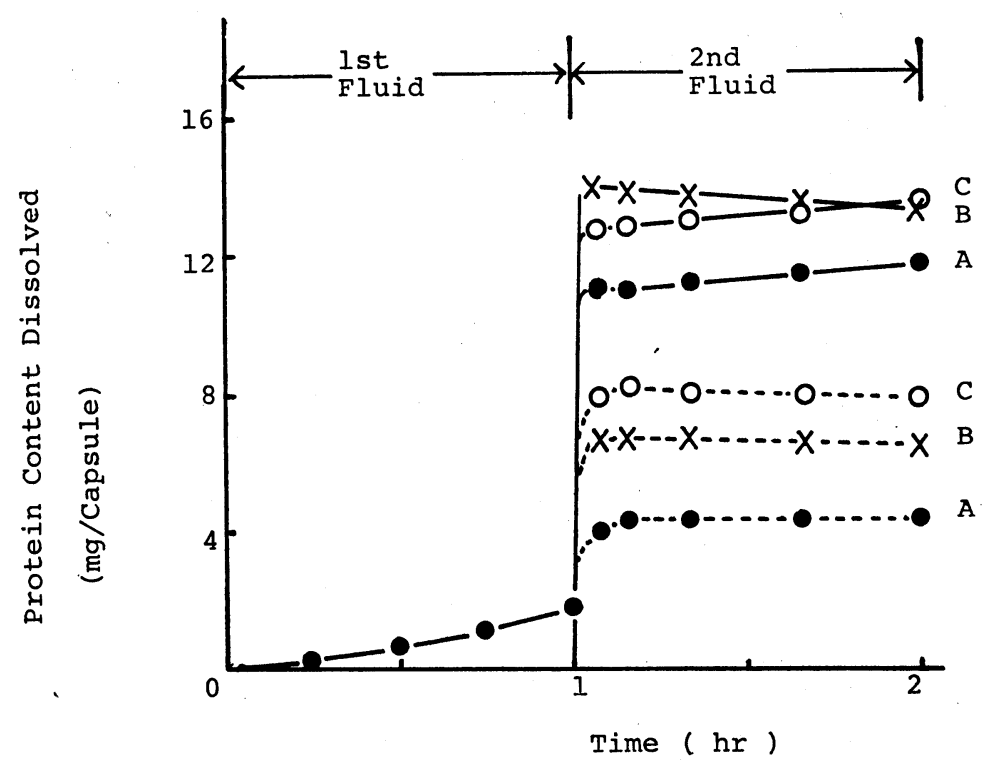

Fig. 5. Seaprose S Dissolved from Capsules in Disintegration Test Fluids (J.P.IX)

- - : Total protein determined from $\mathrm{Cu}-\mathrm{Folin}$ reagent

....... : Active protein calculated from activity

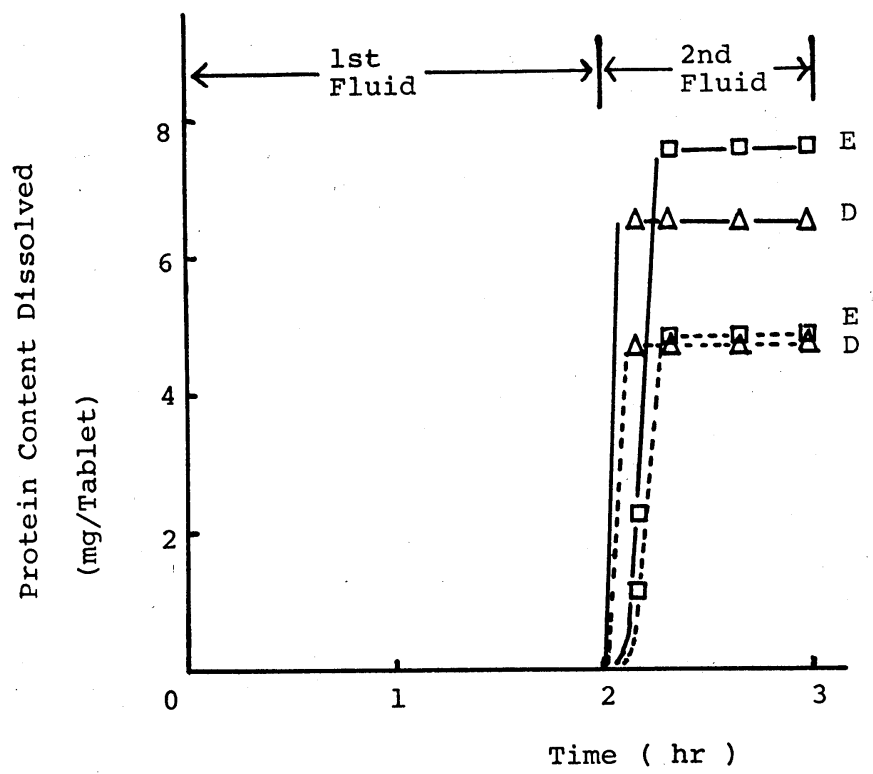

Fig. 6. Seaprose S Dissolved from Tablets in Disintegration Test Fluids (J.P.IX)

- : Total protein determined from $\mathrm{Cu}-\mathrm{Folin}$ reagent

...... : Active protein calculated from activity 


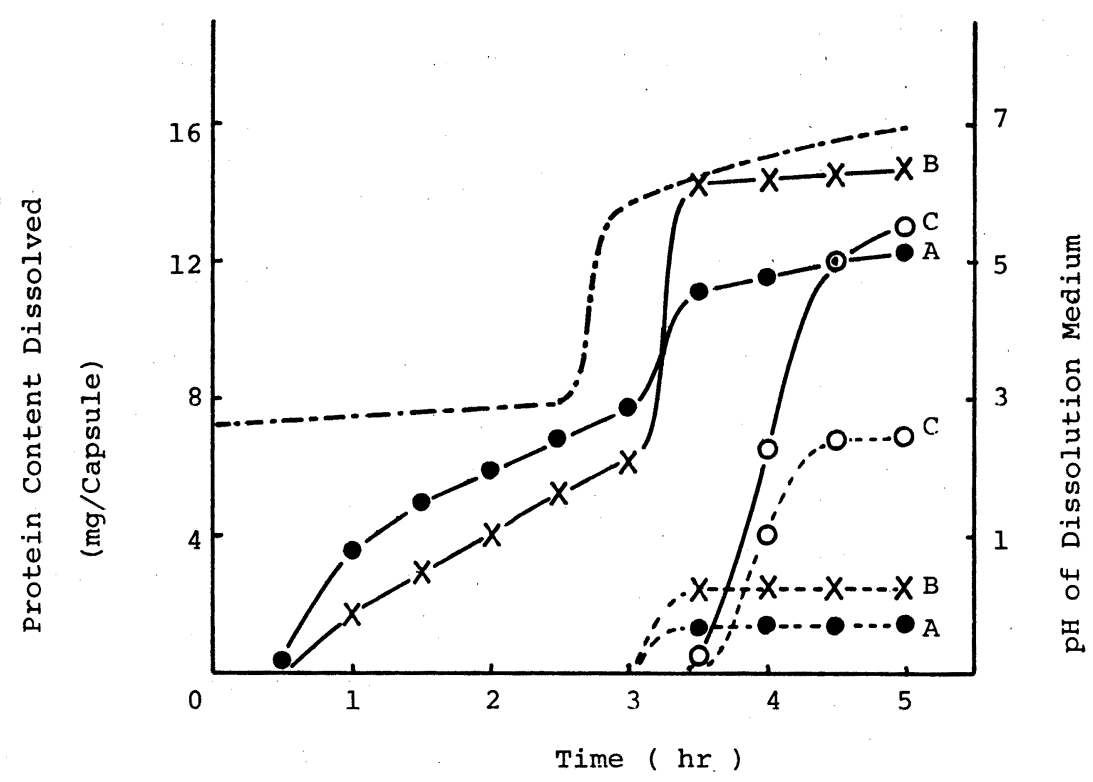

Fig. 7. Seaprose $\mathrm{S}$ Dissolved from Capsules in $\mathrm{pH}$ Shift Test Solution

- : Total protein determined from $\mathrm{Cu}-$ Folin reagent

....... : Active protein calculated from activity $-\cdots-\cdots: \mathrm{pH}$

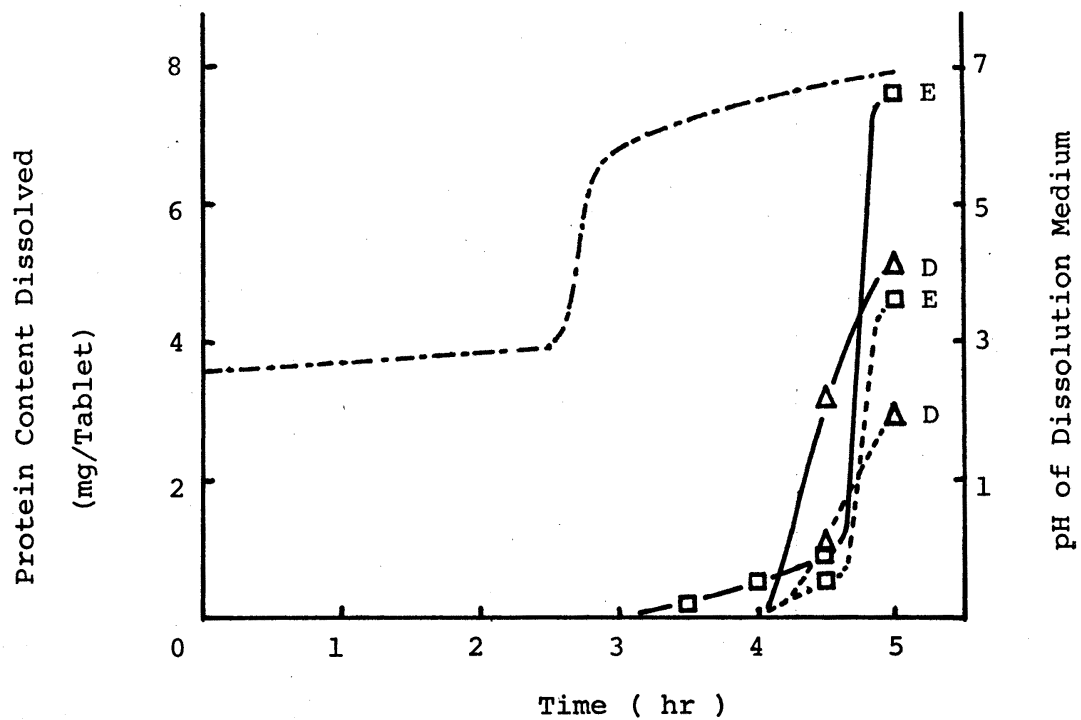

Fig. 8. Seaprose S Dissolved from Tablets in pH Shift Test Solution

Total protein determined from $\mathrm{Cu}-$ Folin reagent

Active protein calculated from activity 
粒を含む試料 A， B およびCについて，溶出するセアプ ローゼS の力価およびたん白量を測定した結果を Fig.7 に示した. 溶出するたん白は, 試料 A では 30 分後に, 試料 $\mathrm{B} て ゙ は 60$ 分後に 認められ，以後 3 時間後まではほ ぼ直線的に増加した。しかし，活性なセアプローゼSは 全く認められないので, セアプローゼ S が試験液に溶出 した段階ではすべて失活した状態にあるといえる。 pHが 急激に上昇した $3 \sim 3.5$ 時間で顆粒は崩壊し， 3.5 時間 後には活性たん白は最高値となったが, 含量試験で得た 平均活性たん白量に比して著しい低下となり, 試料Aは $20 \%$, 試料Bは30\%の活性しか示さなかった。一方, 試 料Cは $\mathrm{pH}$ が 6 以上となる 3.5 時間後に初めて溶出する たん白を認めた. 活性たん白は 4.5 時間後に最高值を示 し, 含量試験での平均活性たん白量の $90 \%$ であったの で,この腸溶性皮膜は試料 AおよびBに比して十分に耐 酸性を有しているといえる.

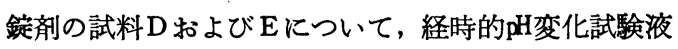
に溶出するセアプローゼSの力価とたん白量を測定した 結果を Fig. 8 に示した. 両試料から溶出するたん白は $\mathrm{pH} 6$ 以上で初めて認められ, 試料Dは 4.5 時間後, 試料 Eは 3.5 時間後であった. また，活性なたん白は両試料 とも 4.5 時間後に認められた. 試料 $\mathrm{D}$ は 5 時間後も一部 の試料は崩壊しなかったので, 活性たん白量はさらに增 加すると考えられる. 一方, 試料 $\mathrm{E} は 4.5 \sim 5$ 時間で崩 壊し, 5 時間後の活性たん白量は含量試験での平均活性 たん白量に等しかった.

\section{結}

5 種類のセアプローゼ $\mathrm{S}$ 製㶡の品質試験を行らため, 重量偏差試験, 含量試験, 溶出試験および腸溶性皮膜の 耐酸性試験を行った。「日局 9 」崩壊試験法の腸溶性の 製剤の項に従って溶出試験を行った結果, 試料Aおよび $\mathrm{B}$ は第 2 液に溶出したセアプローゼ $\mathrm{S}$ の力価が含量試験 の力価に比してかなり低下した. そこで, 試験液に溶出 するセアプローゼ Sの力価とたん白量とを同時に測定し て力価が低下する原因を検討した．その結果，まず第 1 液が腸溶性皮膜内に浸透してセアプローゼSが失活し, その後徐々に溶出してくると推定することができた.

今回の実験結果から, 腸溶性の酵素製剂の品質評価に は, 崩壊試験だけでなく少くとも溶出試験も同時に実施 し, 第 2 液に溶出する酵素力価と, 至適 $\mathrm{pH}$ での酵素力価 を比較して腸溶性皮膜の状態を考察するのが重要である と考えている.

\section{文塥}

1) 田部和久, 千葉幹夫, 門林宗男, 畑田昭雄, 平岡 栄一: 病院薬学, 5, 85 (1979).

2) 田部和久, 門林宗男, 畑田昭雄, 平岡栄一: 病院 薬学, 6, 21 (1980).

3）赤堀四郎編 : 酵贵研究法 第 2 巻, 朝倉書店, 東 京, p. 242 (1956).

4) 日本化学会編 : 実䤅化学講座 23 , 丸善, 東京, p. 39 (1957).

5) 田部和久, 門林宗男, 前田義美, 畑田昭雄, 平岡 栄一: 病院薬学, 4, 199 (1979). 